\title{
Hasil Belajar Akuntansi Keuangan dengan Metode Praktek Langsung Siswa Kelas XI Akuntansi 2 SMK Negeri 1 Rengat
}

\author{
Yetma Martati ${ }^{1}$ \\ ${ }^{1}$ SMK Negeri 1 Rengat \\ e-mail: ${ }^{1}$ yetmamartati11@gmail.com
}

\begin{abstract}
Abstrak
Tujuan penelitian adalah a) meningkatkan pelaksanaan pembelajaran akuntansi keuangan dengan metode praktek langsung, b) meningkatkan pola pengajaran guru, c) meningkatkan peran serta dan antusiasme siswa dalam melaksanakan pembelajaran dan d) meningkatkan kemampuan dan prestasi siswa dalam pembelajaran akuntansi keuangan. Pelaksanaan Penelitian Tindakan Kelas ini terdiri dari tiga siklus, dimana setiap siklus terdiri dari empat komponen yaitu : 1) Perencanaan (planning), 2) Aksi/ Pelaksanaan tindakan (acting), 3) Observasi (obseving), 4) Refleksi (refleting). Jenis data dalam penelitian terdiri dari Data Primer berupa data yang diperoleh secara langsung melalui observasi dan wawancara dengan siswa dan guru yang terlibat langsung dalam pelaksanaan pembelajaran, dan Data Sekunder berupa data yang diperoleh dari sumber-sumber kepustakaan dan literatur yang terkait. Berdasarkan hasil penelitian dapat disimpulkan bahwa metode ini terbukti mampu meningkatkan efektifitas pembelajaran dan meningkatkan nilai uji kompetensi siswa sehingga tepat untuk diterapkan pada pembelajaran. Peningkatan ini menunjukkan bahwa penerapan metode pembelajaran yang tepat dilakukan melalui peningkatan kemampuan menjelaskan materi sehingga menarik dan memotivasi siswa untuk rajin belajar.
\end{abstract}

Kata kunci: Hasil Belajar, Metode Praktek Langsung, Siswa, SMK Negeri 1 Rengat

\begin{abstract}
The research objectives are to a) improve the implementation of financial accounting learning with direct practice methods, b) improve the teaching patterns of teachers, $c$ ) increase the participation and enthusiasm of students in carrying out learning and d) increase the ability and achievement of students in learning financial accounting. Implementation of Classroom Action Research consists of three cycles, where each cycle consists of four components, namely: 1) Planning (planning), 2) Action / Implementation of action (acting), 3) Observation (obseving), 4) Reflection (zipper). The type of data in this study consists of Primary Data in the form of data obtained directly through observation and interviews with students and teachers directly involved in the implementation of learning, and Secondary Data in the form of data obtained from sources of literature and related literature. Based on the results of the study it can be concluded that this method is proven to be able to increase the effectiveness of learning and increase the value of student competency tests so that it is appropriate to be applied to learning. This improvement shows that the application of appropriate learning methods is done through increasing the ability to explain the material so that it attracts and motivates students to study hard.
\end{abstract}

Keywords: Learning Achievemnet, Direct Learning, Student, SMK Negeri 1 Rengat

\section{Pendahuluan}


Pembelajaran akuntansi bagi siswa SMK/sederajad meliputi pengertian dasar dan siklus akuntansi, metode kuantitatif dalam akuntansi dan keterampilan akuntansi. Agar akuntansi menjadi pelajaran yang menarik dan diminati siswa, maka diharapkan guru dapat memilih kegiatan belajar mengajar yang sebanyak mungkin melibatkan siswa agar dapat belajar secara aktif secara fisik, mental maupun sosial demi peningkatan mutu hasil belajar. Pada penyusunan laporan keuangan di segala sektor, perlu adanya ketertiban dalam manajemen usaha dan administrasi pembukuan/ sistem akuntansi dan sesuai dengan Standar Akuntansi Keuangan, sehingga pembelajaran Akuntansi Keuangan badi siswa didik sangat dibutuhkan. Agar setelah mereka selesai dalam menempuh pendidikannya, mereka dapat menerapkan ilmu akuntansi dengan benar kedalam dunia kerja.

Adapun transaksi utama dalam kegiatan akuntansi keuangan adalah transaksi pembelian dan penjualan. Kedua transaksi tersebut sering dilakukan pada segala jenis usaha, sehingga pencatatannya memerlukan ketelitian untuk mengurangi kesalahan yang fatal dalam pencatatan. Untuk menjamin kelengkapan setiap pembukuan, maka dalam proses pencatatan harus dilakukan beberapa hal seperti: 1) setiap transaksi harus dibuatkan bukti pembukuan, 2) setiap pembukuan harus didasarkan atas satu bukti pembukuan yang sah, 3) semua bukti pembukuan harus disimpan secara teratur dan aman.

Siswa akutansi di SMK Negeri 1 Rengat mengalami beberapa kendala dalam menerima pembelajaran Akuntansi Keuangan, dimana masih banyak siswa belum memahami proses memposting transaksi Memposting dari jurnal umum ke buku besar dan laporan keuangan yang didasarkan pada standar akuntansi keuangan. Siswa belum memahami siklus pencatatan dalam akuntansi. Hal ini berimbas pada nilai akademik dan prestasi siswa dalam bidang studi Akuntansi Keuangan masih minim. Penulisan penelitian tindakan Kelas ini bertujuan untuk memperoleh solusi yang tepat guna mengatasi berbagai permasalahan yang dimaksudkan tersebut. Solusi yang ditawarkan tentu saja bersifat sangat preventif guna kebaikan bersama, sehingga dapat meningkatkan kemampuan dan menigkatkan prestasi siswa dalam bidang studi Akuntansi Keuangan.

Penelitian ini dibatasi oleh beberapa kajian khusus yang disesuaikan dengan judul penelitian untuk menunjukkan batasan analisis yang dilakukan oleh peneliti. Dilakukan pembatasan masalah agar hasil penelitian ini sesuai dengan tujuan yang ingin dicapai yaitu meningkatkan pemahaman siswa dalam memposting transaksi ke dalam buku besar. Pelaksanaan penelitian tindakan Kelas ini di batasi dalam skala mikro yaitu pada siswa Kelas XI Akuntasi 2 di SMK Negeri I Rengat pada pembelajaran akuntansi keuangan dengan menerapkan metode praktek langsung. Melalui pembatasan masalah ini diharapkan penelitian ini fokus terhadap tujuan yang telah ditetapkan peneliti dan tidak melebar kedalam disiplin ilmu lainnya.

Tujuan yang hendak dicapai dalam penelitian ini adalah untuk meningkatkan pengetahuan dan prestasi siswa dalam pembelajaran Akuntansi Keuangan dengan metode praktek langsung memposting dari jurnal umum ke buku besar dan laporan keuangan. Penelitian ini lebih memfokuskan kajiannya pada penemuan fakta dan kenyataan di lapangan.

Metode prektik langsung adalah metode yang dilakukan oleh guru dengan cara melakukan praktek secara langsung sesuai dengan materi yang akan disampaikan kepada siswa. Melalui kegiatan ini diharapkan siswa mendapatkan pengalaman melalui interaksi langsung dengan objek. Praktek langsung adalah proses belajar mengajar yang dilakukan oleh guru dengan cara melakukan praktek secara langsung sesuai dengan materi yang disampaikan kepada siswa. Metode praktek merupakan metode mengajar dimana siswa melaksanakan kegiatan latihan praktek agar siswa memiliki ketegasan atau keterampilan yng lebih tinggi dari apa yang telah dipelajari.

\section{Metode Penelitian}

\subsection{Waktu dan Tempat}

Penelitian tindakan kelas ini dilaksanakan pada semester ganjil tahun pelajaran 2016/2017 selama kurun waktu 3 (tiga) bulan mulai dari September sampai November 2016 dengan lokasi penelitian di SMK Negeri I Rengat yang beralamatkan di Jalan Sultan KM 4 
Rengat, Indragiri Hulu, Riau. Penentuan lokasi penelitian ini lebih didasarkan pada kemudahan dalam memperoleh data, dimana peneliti sendiri adalah guru pengampu yang memberikan pembelajaran Akuntansi Keuangan pada siswa. Sehingga peneliti dapat melakukan pengamatan langsung dan tidak mengganggu kewajibannya sebagai tenaga pendidik, dimana kedua hal tersebut dapat dilakukan secara bersamaan. Penelitian tindakan kelas ini dilaksanakan pada tanggal 1 september s.d 30 November 2016.

\subsection{Rancangan Penelitian}

Penelitian tindakan kelas ini dilaksanakan dalam 3 siklus dengan perencanaan kegiatan sebagai berikut

\begin{tabular}{cccclc}
\hline No & Tanggal & Pert & Siklus & \multicolumn{1}{c}{ Materi } & Waktu \\
\hline $\mathbf{1}$ & 1 September 2016 & 1 & 1 & Siklus akuntansi perusahaan dagang & 2 Jp \\
$\mathbf{2}$ & 6 September 2016 & 2 & 1 & Penyiapan transaksi / bukti transaksi & 2 Jp \\
$\mathbf{3}$ & 8 september 2016 & 1 & 2 & Memproses entri Jurnal & 2 Jp \\
$\mathbf{4}$ & 13 september 2016 & 2 & 2 & Memproses entri jurnal & 2 Jp \\
$\mathbf{5}$ & 15 september 2016 & 3 & 2 & Memproses entri jurnal & 2 Jp \\
$\mathbf{6}$ & 20 september 2016 & 4 & 2 & Memproses entri jurnal & 2 Jp \\
$\mathbf{7}$ & 22 september 2016 & 1 & 3 & Pemprosesan akun buku besar & 2 Jp \\
$\mathbf{8}$ & 27 september 2016 & 2 & 3 & Pemprosesan akun buku besar & 2 Jp \\
$\mathbf{9}$ & 29 september 2016 & 3 & 3 & Membukukan jurnal ke buku besar & 2 Jp \\
$\mathbf{1 0}$ & 4 oktober 2016 & 4 & 3 & Membukukan jurnal ke buku besar & 2 Jp \\
\hline
\end{tabular}

\subsection{Subjek Penelitian}

Subjek dalam penelitian ini adalah kajian utama dalam penelitian ini karena penelitian ini merupakan partisipasi kolaboratif, dimana peneliti ikut serta dalam aktivitas pembelajaran untuk melakukan penelitian. Objek dalam penelitian yaitu siswa Kelas XI Akuntasi 2..

\subsection{Sumber dan Teknik Pengumpulan Data}

Data yang digunakan dan dikumpulkan dalam penelitian ini adalah data yang berupa cuplikan hasil wawancara, hasil observasi, dan dokumen-dokumen yang mendukung dalam penelitian seperti catatan-catatan atau dokumen resmi sekolah di SMK Negeri I Rengat. Sumber data dari data-data yang diambil adalah lingkup sekolah di SMK Negeri I Rengat dan yang menjadi nara sumbernya adalah beberapa orang dari warga sekolah seperti kepala sekolah, guru, karyawan, dan siswa atau warga sekolah yang lainnya sejauh bisa memberikan informasi yang berkaitan dengan pelaksanaan pembelajaran Akuntansi Keuangan.

Jenis data dalam penlitian ini dikelompokkan menjadi dua yaitu:

a. Data Primer

Berupa data yang diperoleh secra langsung dari lokasi penelitian yaitu di SMK Negeri I Rengat, dengan melakukan observasi dan wawancara dengan siswa dan guru lain yang terlibat secara langsung dalam pelaksanaan pembelajaran Akuntansi Keuangan. Data tersebut berupa: data siswa, pelaksanaan pembelajaran, kendalakendala dalam PBM, nilai siswa, dan peningkatan kemampuan siswa dalam memposting.

b. Data Sekunder 
Data sekunder berupa data yang diperoleh dari sumber-sumber kepustakaan dan literatur yang berhubungan dengan perusahaan termasuk catatan-catatan yang bersumber dari informasi sekolahan seperti sejarah berdirinya sekolahan, profil sekolah, Silabus dan RPP mata pelajaran Akuntansi Keuangan dan nilai akademik siswa.

Untuk memperoleh data-data pendukung agar penelitian memberikan hasil yang diinginkan seperti pada hipotesis penelitian, maka peneliti melakukan pengumpulan data. Peneliti menjadi instrumen dalam penelitian ini dengan melakukan pengumpulan data yang bersifat interaktif dan non interaktif. Teknik interaktif yang dilakukan berupa wawancara dan observasi, sedangkan teknik non interaktif berupa pemeriksaan dokumen sekolahan dan studi pustaka.

\subsection{Teknik Analisis Data}

Proses analisis data dalam Penelitian Tindakan Kelas yang bersifat penelitian kualitatif merupakan tahap penyederhanaan data agar lebih mudah dibaca, dipahami dan diinterprestasikan. Penelitian kualitatif memandang sekumpulan data yang diperoleh sebagai produk yang di dalamnya sudah terkandung makna yang mempunyi referensi pada nilai dan informasi untuk mendukung penelitian. Kegiatan analisis dalam penelitian kualitatif hanya merupakan rekontruksi dari kontruksi sebelumnya. Metode yang digunakan dalam analisis data kualitatif yaitu menganalisis data yang didasarkan pada kualitas data yang digunakan untuk memecahkan permasalahan pokok penelitian, kemudian diuraikan dalam bentuk bahasa deskriptif.

Teknik analisis data dalam penelitian ini menggunakan teknik domain, teknik komponensial, dan teknik tema. Analisis domain digunakan untuk mengungkapkan secara umum tentang permasalahan-permasalahan yang berkaitan dengan manajemen partisipasi masyarakat dalam peningkatan mutu pendidikan. Analisis komponen digunakan untuk mencari secara sistematis atribut-atribut dan komponen-komponen yang berkaitan dengan permasalahanpermasalahan di atas. Analisis ini melibatkan seluruh proses pencarian, proses memilah-milah, dan mengelompokkan dalam satu dimensi kontras tertentu, sehingga akan ditemukan beberapa kontras yang muncul. Sedangkan analisis tema digunakan untuk menemukan tema-tema yang muncul selama proses penelitian berlangsung baik tema-tema yang bersifat eksplisit maupu inplisit tentang permasalahan-permasalahan yang berkaitan dengan pengelolaan pengawas sekolah.

Pada penerapan metode baru tidak akan berdampak terlalu banyak, hal ini disebabkan karena perlu adanya adaptasi dan sosialisasi bagi semua elemen yang terlibat di dalamnya seperti guru, siswa dan kepala sekolah dan pihak-pihak yang terkait lainnya. Sehingga diperlukan sosialisasi oleh peneliti kepada pihak-pihak tersebut mengenai metode pembelajaran yang akan diterapkan. Melalui peningkatan pembelajaran Akuntansi Keuangan diharapkan akan memberikan perubahan yang positif yang dapat menjadikan sekolahan unggulan. Untuk mengetahui keberhasilan tersebut maka dilakukan evaluasi, wawancara dan tes mengenai ateri yang diajarkan pada objek penelitian dengan nilai interval sebagai berikut.

Tabel 1. Interval Hasil Tes pada Siswa

\begin{tabular}{ccl}
\hline No & Interval & \multicolumn{1}{c}{ Keterangan } \\
\hline $\mathbf{1}$ & $86-100$ & Nilai Tes Akuntansi Keuangan Amat Baik \\
$\mathbf{2}$ & $70-85$ & Nilai Tes Akuntansi Keuangan Baik \\
$\mathbf{3}$ & $60-69$ & Nilai Tes Akuntansi Keuangan Cukup \\
$\mathbf{4}$ & $\leq 59$ & Nilai Tes Akuntansi Keuangan Kurang \\
\hline
\end{tabular}




\subsection{Prosedur Penelitian}

Berkaitan dengan jenis penelitian ini yaitu deskriptif kualitatif maka prosedur penelitian ini menghasilkan data dengan perilaku yang diamati (dalam Moleong, 1995). Penelitian deskriptif kualitatif adalah suatu penelitian yang ditujukan untuk mendeskripsikan dan menganalisis fenomena, peristiwa, kepercayaan, persepsi, pemikiran orang secara individual maupun kelompok. Penelitian ini bertujuan menggambarkan dan mengungkap serta mencari dan menemukan makna dari hal-hal yang terjadi (Sukamadinata, 2005). Data yang dikumpulkan peneliti berupa data verbal dan perilaku subjek penelitian yaitu makna-makna dan konteks perilaku yang mengarah pada pemahaman yang lebih luas tentang makna dan konteks tingkah laku dan proses yang terjadi dalam pola-pola amatan dari faktor-faktor yang berhubungan dengan peningkatan pembelajaran Akuntansi Keuangan.

Pelaksanaan Penelitian Tindakan Kelas ini terdiri dari tiga siklus, dimana setiap siklus terdiri dari empat komponen yaitu : 1) Perencanaan (planning), 2) Aksi/ Pelaksanaan tindakan (acting), 3) Observasi (obseving), 4) Refleksi (refleting). Dimana setiap siklus saling berkaitan dan berhubungan, karena hasil refleksi akan digunakan sebagai acuan untuk perbaikan pada siklus berikutnya. Diharapkan setiap siklus ada peningkatan yang signifikan mengenai peningkatan pembelajaran Akuntansi Keuangan sehingga hasil akhir akan maksimal. Peneliti mengadakan perubahan dan peningkatan dalam melaksanakan pembelajaran di setiap siklusnya.

\section{Hasil dan Pembahasan \\ 3.1 Deskripsi Pra Siklus}

Kondisi pra siklus merupakan kondisi dimana sebelum diterapkan metode praktek langsung untuk memposting tarnsaksi pembelian dan penjualan ke dalam buku besar. Dimana pelaksanaan pembelajaran Akuntansi Keuangan masih menggunakan metode pembelajaran yang tradisional, dengan cara guru ceramah didepan Kelas untuk menyampaiakan materi pelajaran dan siswa memperhatikannya dibelakang. Metode ini dinilai kurang efektif sehingga siswa tidak dapat menyerap ilmu pelajaran yang disampaiakan. Hal ini berimbas pada nilai akademis yang diperoleh siswa menjadi rendah. Untuk mendapatkan gambaran pada kondisi pra siklus ini maka peneliti melakukan uji kompentesi pada siswa pada bidang studi Akuntansi Keuangan khususnya mengenai meteri pelajaran memposting buku besar. Hasil nilai uji kompetensi pada kondisi pra siklus adalah sebagai berikut:

Tabel 2. Nilai Uji Kompetensi Pra Siklus

\begin{tabular}{cllccccc}
\hline No & Kategori & Interval & $\mathbf{X}$ & $\mathbf{F}$ & $\mathbf{F}(\mathbf{X})$ & \% & Keterangan \\
\hline $\mathbf{1}$ & Amat Baik & $86-100$ & 93 & 4 & 372 & 18.84 & 68.10 \\
$\mathbf{2}$ & Baik & $70-85$ & 78 & 6 & 468 & 23.70 & \\
$\mathbf{3}$ & Cukup & $60-69$ & 65 & 9 & 585 & 29.62 & \\
$\mathbf{4}$ & Kurang & $\leq 59$ & 55 & 10 & 550 & 27.85 & \\
& Jumlah & & & 29 & 1975 & 100,00 & CUKUP \\
\hline
\end{tabular}

Dari hasil uji kompetensi diatas dapat diketahui bahwa nilai rata-rata siswa sebesar 68,10 , dimana nilai tersebut masih dibawah standar sehingga perlu ditingkatkan. Peneliti berupaya untuk mengatasi permasalahan tersebut dengan menerapkan metode baru dalam pelaksanaan pembelajaran Akuntansi Keuangan, yaitu dengan menerapkan metode praktek langsung untuk memposting transaksi pembelian dan penjualan ke dalam buku besar. Melalui penerapan metode baru tersebut diharapkan terjadi peningkatan dalam pembelajaran Akuntansi Keuangan, sehingga nilai akademis siswa dapat meningkat pula.

\subsection{Hasil Pelaksanaan Tindakan}

\subsubsection{Siklus 1}

Pada awal tindakan peneliti yang juga berperan sebagai guru pengampu pelajaran meberikan penjelasan pada siswa mengenai penerapan metode pembelajaran yang baru. 
Diamana siswa akan diajarkan untuk praktek langsung memposting transaksi kedalam buku besar. Sehingga tidak ada perbedaan persepsi salama pelaksanaan pembelajaran.

1. Tindakan Perencanaan

a. Setelah melakukan sosialisasi dan penjelasan mengenai metode baru yang akan diterapkan, maka selanjutnya peneliti mempersiapkan materi yang akan di ajarkan kepada siswa yaitu tentang kegiatan memposting ke buku besar.

b. Kemudian peneliti menetapkan rancangan langkah-langkah kegiatan yang akan dilakukan ketika melakukan proses belajar mengajar.

2. Pelaksanaan Tindakan

a. Siswa diberikan buku materi pelajaran Akuntansi Keuangan yang dapat dipelajari sewaktu-waktu.

b. Peneliti memberikan penjelasan mengenai matari pelajaran memposting ke dalam buku besar secara rinci pada siswa.

c. Bagi siswa yang belum paham diminta untuk bertanya pada guru.

d. Peneliti menjelaskan alur pembukuan dalam akuntansi keuangan.

e. Peneliti memberikan tugas (uji kompetensi) pada siswa untuk melakukan posting transaksi pembelian dan penjualan ke dalam buku besar.

f. Peneliti melakukan evaluasi bersama siswa terhadap hasil tugas yang telah dikerjakan.

g. Peneliti melakukan diskusi bersama siswa mengenai hasil evaluasi.

3. Refleksi

Untuk mengetahui keberhasilan pada siklus I maka peneliti melakukan refleksi. Untuk mengetahui hasil pada siklus I maka dilakukan uji kompetensi pada siswa dimana pada akhir pelajaran siswa diberi tugas untuk dikerjakan. Terdapat peningkatan nilai dalam bidang studi Akuntansi Keuangan dibandingkan dengan kondisi pra siklus.

Tabel 3. Nilai Uji Kompetensi Siklus I

\begin{tabular}{cllccccc}
\hline No & Kategori & Interval & X & F & F $(\mathbf{X})$ & \% & Keterangan \\
\hline $\mathbf{1}$ & Amat Baik & $86-100$ & 93 & 6 & 558 & 26.87 & 71.62 \\
$\mathbf{2}$ & Baik & $70-85$ & 78 & 8 & 624 & 30.04 & \\
$\mathbf{3}$ & Cukup & $60-69$ & 65 & 7 & 455 & 21.91 & \\
$\mathbf{4}$ & Kurang & $\leq 59$ & 55 & 8 & 440 & 21.18 & \\
& Jumlah & & & 29 & 2077 & & BAIK \\
\hline
\end{tabular}

Dari tabel uji kompetensi pada siklus I di atas dapat diketahui bahwa nilai siswa mengalami peningkatan apabila dibandingkan dengan hasil pra siklus. Nilai uji kompetensi siswa dari 68,10 menjadi 71,62. Peningkatan ini merupakan hasil dari upaya yang dilakukan oleh guru dalam mengadakan peningkatan dan perubahan metode pembelajaran Akuntansi Keuangan.

\subsubsection{Siklus 2}

1. Tindakan Perencanaan

Pada siklus II peneliti kembali melakukan peningkatan dalam pembelajaran Akuntansi Keuangan. Siklus II diawali dengan menyusun rencana perbaikan yang nantinya akan diimplementasikan dalam pelaksanaan. Dengan memadukan hasil refleksi daur I dan rencana daur II, diharapkan terjadi peningkatan kemampuan siswa dalam memposting. Maka peneliti kembali menyusun rencana perbaikan pembelajaran. 
a. Peneliti mempersiapakan materi pembelajaran Akuntansi Keuangan.

b. Peneliti mempersiapakan lembar observasi dan evaluasi untuk mengetahui perubahan dan peningkatan pada siswa.

c. Peneliti mempersiapkan tugas-tugas untuk siswa.

2. Pelaksanaan Tindakan

Peneliti memberikan penjelaskan mengenai materi pelajaran pada siswa secara mendetail. Selanjutnya peneliti memberikan contoh soal mengenai tahap memposting pada transaksi pembelian dan penjualan sebagai berikut:

Soal transaksi penjualan :

Pada tanggal 2 Pebruari 2002, diterima per kas atas penjualan barang dagangan seharga Rp 150.000,00.

Soal transaksi pembelian :

Pada tanggal 4 Pebruari 2002, dibeli secara tunai peralatan toko seharga Rp 500.000,00 dari UD Supriyadi

Setelah peneliti memberikan contoh tersebut, kemudian bersama-sama peneliti memandu siswa dalam mengerjakannya. Peneliti menulis jawaban dengan cara menggambarkan buku besar di papan tulis sambil menjelaskannya pada siswa. Selama peneliti selesai memberikan penjelasan maka siswa baru mencatatnya di buku masing-masing sehingga konsentrasi siswa tidak terbagi dalam memperhatikan penjelasan peneliti di depan Kelas. Selanjutnya siswa di beri tugas untuk memposting transaksi Memposting dari jurnal umum ke BB dan L/K ke dalam buku besar secara individu. Setelah selasai maka selanjutnya di adakan diskusi dan evaluasi bersama seluruh siswa mengenai tugas yang telah mereka kerjakan. Pada diskusi kali ini diadakan sesi tanya jawab antar peneliti dan siswa untuk meningkatkan pengetahuan siswa dalam memposting.

3. Observasi

Selama melakukan pembelajaran dengan metode praktek lansung, peneliti melakukan observasi. Pada siklus II ini peneliti pandai memotivasi siswa untuk memperhatikan saat peneliti memberikan penjelasan di depan Kelas. Melalui contoh pencatatan transaksi kedalam buku besar yang diberikan oleh peneliti maka siswa lebih memahami teknik memposting yang benar berdasarkan standar yang berlaku. Melalui tes uji kompetensi yang diberikan, menunjukkan siswa dapat praktek secara langsung untuk melakukan posting transaksi Memposting dari jurnal umum ke BB dan L/K ke dalam buku besar.

4. Refleksi

Perubahan yang dilakukan guru dalam penyampaian pelajaran telah dapat meningkatkan kemampuan siswa dalam melakukan posting ke dalam buku besar. Siswa mulai memahami cara melakukan pencatatan dengan benar. Sehingga nilai siswa dalam uji kompetensi mengalami peningkatan semula pada siklus I sebesar 71,62 menjadi 74,31. Peningkatan ini merupakan bukti efetifitas penerapan metode praktek langsung pada pembelajaran Akuntansi Keuangan.

Tabel 4. Nilai Uji Kompetensi Siklus II

\begin{tabular}{cllccccc}
\hline No & Kategori & Interval & X & F & F (X) & \% & Keterangan \\
\hline $\mathbf{1}$ & Amat Baik & $86-100$ & 93 & 9 & 837 & 38.84 & 74.31 \\
$\mathbf{2}$ & Baik & $70-85$ & 78 & 6 & 468 & 21.72 & \\
$\mathbf{3}$ & Cukup & $60-69$ & 65 & 8 & 520 & 24.13 & \\
$\mathbf{4}$ & Kurang & $\leq 59$ & 55 & 6 & 330 & 15.31 & \\
& Jumlah & & & 29 & 2155 & & BAIK \\
\hline
\end{tabular}

\subsubsection{Siklus III}

Peningkatan hasil pada siklus II belum menunjukkan hasil yang maksimal sehingga penelitian dilanjutkan kembali pada siklus III. Pada siklus III ini peneliti kembali melakukan perbaikan dalam pembelajaran dengan memberikan berbagai tugas tambahan pada siswa.

\section{Tindakan Perencanaan}

Peneliti kembali menyusun rencana perbaikan pada pelaksanan tindakan agar doperoleh hasil yang maksimal. Peneliti mempersiapkan beberapa sarana prasarana pendukung pembelajaran dan tugas yang akan diberikan pada siswa. Secara lebih rinci perencanaan yang disusun peneliti adalah: 
a. Mempersiapkan materi pelajaran tentang memposting dan buku besar

b. Mempersiapkan OHP yang digunakan untuk penyampaian materi pelajaran.

c. Mempersiapkan buku catatan untuk observasi tentang peningkatan hasil.

d. Mempersiapkan tugas rumah dan tugas di sekolah bagi siswa.

\section{Pelaksanaan Tindakan}

Setelah perencanaan selesai di persiapan maka selanjutnya dilaksanakan pembelajaran di Kelas. Di awali dengan penjelasan materi secara lengkap oleh peneliti dengan menggunakan media pendukung OHP. Peneliti menjelakskan berbagai macam transaksi pembelian dan penjualan yaitu secara kredit dan tunai. Siswa dapat memperhatihan slide buku besar yang ditunjukkan oleh peneliti melalui OHP. Pada saat menjelaskan materi, peneliti kembali memberikan cotoh soal mengenai teknik memposting.

Soal transaksi penjualan :

Pada tanggal 4 April 2003 diterima kas atas penjualan barang dagangan sebesar Rp 700.000.

Soal transaksi pembelian :

Pada tanggal 10 April 2003 di beli secara kredit peralatan kantor dari UD. Rejeki seharga Rp 400.000, dengan uang muka Rp 250.000.

Setelah penjelasan dari peneliti telah selesai, maka selanjutnya peneliti memberikan tugas pada siswa untuk dikerjakan yaitu melakukan posting ke dalam buku besar pada soal-soal transaksi yang telah diberikan. Di akhir pertemuan siswa diberi pekerjaan rumah untuk mengerjakan tugas yang sama namun dengan soal-sola yang berbeda. Peneliti kembali melakukan diskusi dengan siswa mengenai tugas-tugas yang telah dikerjakan tersebut kemudian mengoreksi hasil pekerjaan siswa.

\section{Observasi}

Penyampaian materi pelajaran dengan menggunakan OHP telah menarik perhatian siswa dan membantu siswa dalam memahami materi yang disampaikan peneliti. Siswa sangat antusias dalam mengerjakan tugas-tugas yang diberikan, semua juga mengumpulkan pekerjaan rumah yang telah diberikan pada pertemuan selanjutnya. Melalui kegiatan diskusi diakhir pelajaran maka dapat di ketahui siswa yang belum paham dan siswa yang belum memahami teknik-teknik memposting. Bagi siswa yang kurang paham maka diberi penjelasan lebih oleh peneliti.

\section{Refleksi}

Melalui penggunaan media pendidikan berupa OHP pada penyampaian materi dan pemberian tugas di sekolah serta penerapan metode praktek langsung untuk memposting transaksi ke dalam buku besar maka dapat meningkatkan kemampuan dan pengetahuan siswa mengenai teknik memposting yang benar. Nilai uji kompetensi pada siklus III juga mengalami peningkatan, dimana peningkatan tersebut merupakan hasil yang paling maksimal bila dibandingkan dengan hasil pada siklus sebelumnya yaitu sebesar 80,38, dimana sebagian besar siswa mendapatkan nilai yang baik.

Tabel 5. Tabel 4. Nilai Uji Kompetensi Siklus II

\begin{tabular}{cllccccc}
\hline No & Kategori & Interval & $\mathbf{X}$ & $\mathbf{F}$ & $\mathbf{F}(\mathbf{X})$ & $\mathbf{\%}$ & Keterangan \\
\hline $\mathbf{1}$ & Amat Baik & $86-100$ & 93 & 12 & 1116 & 47.88 & 80.38 \\
$\mathbf{2}$ & Baik & $70-85$ & 78 & 10 & 780 & 33.46 & \\
$\mathbf{3}$ & Cukup & $60-69$ & 65 & 5 & 325 & 13.94 & \\
$\mathbf{4}$ & Kurang & $\leq 59$ & 55 & 2 & 110 & 4.72 & \\
& Jumlah & & & 29 & 2331 & & BAIK \\
\hline
\end{tabular}

Hasil Tes di SMK Negeri I Rengat 
Ket: $X$ : Nilai tengah, $F$ : Frekuensi (jumlah siswa), $F(X)$ : Nilai tengah $x$ Frekuensi dan Nilai rata-rata siswa $=2331 / 29=80.38$

\subsection{Pembahasan}

Pada bagian ini akan membandingkan hasil yang diperoleh pada setiap siklus. Pada kondisi pra siklus pelaksanaan pembelajaran Akuntansi Keuangan masih menggunakan metode pembelajaran yang tradisional sehingga belum diterapkan metode praktek langsung untuk memposting tarnsaksi pembelian dan penjualan ke dalam buku besar. Metode ini dinilai kurang efektif sehingga siswa tidak dapat menyerap ilmu pelajaran yang disampaikan dan tidak memahami tentang teknik memposting yang tepat. Kemampuan pada siswa yang kurang menyebabkan perolehan nilai pada uji kompetensi menjadi minim yaitu sebesar 68,10. Berdasarkan nilai interval yang dibuat peneliti maka nilai tersebut tergolong cukup. Siswa yang memperoleh nilai antara 86-100 belum ada.

Untuk mengatasi kendala tersebut maka peneliti melakukan perubahan pada pelaksanaan pembelajaran dengan menerapkan metode praktek langsung memposting pada buku besar. Pada siklus I siswa diberikan buku materi pelajaran Akuntansi Keuangan, peneliti memberikan penjelasan mengenai materi pelajaran kemudian memberikan tugas pada siswa. Hasil uji kompetensi pada siklus I mengalami peningkatan menjadi 71,62, dimana siswa yang memperoleh nilai 86-100 sebanyak enam orang dan tergolong dalam kategori baik. Peneliti kembali magadakan perubahan pada siklus II dengan memberikan contoh-contoh soal mengenai teknik memposting pada siswa. Sehingga siswa lebih memahami cara memposting ke buku besar. Hal ini di tunjukkan pada perolehan hasil uji kompetensi pada siklus II menjadi 74,31. Siswa yang memperoleh nilai 86-100 sebanyak sembilan orang.

Peningkatan hasil yang maksimal diperoleh pada siklus III yaitu sebesar 80,38, dimana siswa yang memperoleh nilai 86-100 sebanyak dua belas orang dari 29 siswa. Peningkatan ini diperoleh setelah peneliti menggunakan OHP sebagai sarana pengajaran dan memberikan tugas rumah pada siswa.

Tabel 6. Peningkatan Nilai Setiap Siklus

\begin{tabular}{lcccc}
\hline Keterangan & Pra Siklus & Siklus I & Siklus 2 & Siklus 3 \\
\hline Nilai Ujian Kompetensi & 68,10 & 71,62 & 74,31 & 80,38 \\
\hline
\end{tabular}

\section{Kesimpulan}

Berdasarkan hasil penelitian dapat disimpulkan bahwa penerapan metode praktek langsung memposting transaksi pembelian dan penjualan pada pelaksanaan pembelajaran Akuntansi Keuangan dapat meningkatkan kualitas pembelajaran dan pemahaman siswa dengan rincian, pada kondisi pra siklus pelaksanaan pembelajaran menggunakan metode pembelajaran tradisional masih kurang efektif sehingga siswa tidak dapat menyerap ilmu yang disampaikan dan tidak memahami tentang teknik memposting yang tepat dengan nilai uji kompetensi 68,10 yang tergolong cukup serta belum ada siswa memperoleh nilai 86-100. Peningkatan maksimal diperoleh pada siklus III dengan nilai hasil uji kompetensi menjadi 80,38 dan jumlah siswa yang memperoleh nilai 86-100 meningkat menjadi 12 (dua belas) orang. Peningkatan ini diperoleh setelah peneliti menggunakan OHP sebagai sarana pengajaran dan memberikan tugas rumah pada siswa.

\section{Daftar Pustaka}

[1] Bloom, Benyamin, S. 1974. Taxonomy of Educational Objectives. New York: David, Mc. Coy, Inc.

[2] Departemen Pendidikan dan Kebudayaan. 1993. Profil Kemampuan Guru Sekolah Lanjutan, Jakarta : Ditjen Dikti Depdikbud.

[3] Jurusan PPB-IKIP Bandung. 1986. Psikologi Pembelajaran dan Pengajaran. Bandung.

[4] Miles B. Matthew dan Huberman A. Michael. 1992. Analisis Data Kualitatif. Jakarta: UI Press 
[5] Moleong, Lexy. 2006. Metodologi Penelitian Kualitatif. Bandung: Remaja Karya

[6] Natawidjaja, Rochman. 1996. Pokok-pokok Pikiran mengenai Penelitian Keias, Makalah. Jakarta: Ditjen Dikti Dikbud.

[7] Sardiman, A.M. 1996. Interaksi dan Motivasi Belajar Mengajar. Jakarta: Raja Grafindo Persada.

[8] Sudibyo dkk. 2002. Prinsip Prinsip Akuntansi Untuk SMU/ Sederajat. Bogor: Yudistira.

[9] Sudjana, Nana. 1995. Dasar-dasar Proses Belajar Mengajar, Bandung: Sinar Baru Algesindo.

[10] Sumantri, Hendi. 2000. Akuntansi Keuangan SMK. Bandung: Amriko.

[11] Sutopo, H.B. 2002. Metodologi Penelitian Kualitatif. UNS Press.

[12] Suyoto. 1996. Akuntansi Keuangan Untuk Sekolah Menengah Kejuruan Kelompok Bisnis dan Manajemen. Bandung: Titian Ilmu.

[13] Wiriaatmadja, Rochiati. 2007. Metode Penelitian Tindakan Kelas. Bandung: Remaja Rosdakarya.

[14] Zainal, Aqib. 2006. Penelitian Tindakan Kelas. Bandung: Yrama Widya.

[15] Zaini, Hisyam. 2007. Strategi Pembelajaran Aktif. Yogyakarta: CTSD. 